\title{
Junior Competition Conference 2019
}

One of the key highlights of the competition law calendar has always been the Annual Junior Competition Conference (JCC), which brought together junior members of the competition law community, from all professional backgrounds, for a half-day conference held at the Competition Appeal Tribunal (CAT) in London. Whilst there are a large number of conferences held each year on competition law, these were generally aimed at and attended by more senior colleagues; the JCC thus somewhat filled a gap in the market, particularly as it was also always free to attend. It was therefore always eagerly anticipated.

The JCC had always been organized by the editors of the Competition Law Journal. Therefore, with the relaunch of the Competition Law Journal by Edward Elgar Publishing in 2018, we were keen to also reestablish the JCC, not least because - even during the Journal's publishing hiatus - we were regularly receiving requests to do so. Accordingly, after a break in 2018, we were very pleased to hold the 12th Junior Competition Conference on 10 May 2019. We were again very kindly hosted by the CAT, with the CAT President (and Consultant Editor of the Journal) Sir Peter Roth very kindly welcoming attendees with a thought-provoking speech on the continued importance of competition law in which he observed that there had never been a more exciting time to practice competition law. In all, around 100 colleagues from law firms, barristers' chambers, in-house legal departments, economics consultancies, competition and regulatory authorities and the specialist competition media attended. We welcomed attendees from London, the rest of the UK and a number of other countries.

We chose, as is usual, two themes for the conference. These were Recent developments in competition litigation and Vertical restraints in the online age: where next?, which we considered were both highly topical and deserving of scrutiny and in-depth discussion in a conference setting. This was confirmed by the very high quality of the proposals that we received in response to our call for speakers and the lively debate that followed the presentations on both topics. Whittling the proposals down to a number that we could accommodate was very difficult and we are grateful to all who made proposals.

The panel on Recent developments in competition litigation was chaired by Anneli Howard, of Monckton Chambers. Presentations were given by John Kwan of Cleary Gottlieb, Emma Mockford of Brick Court Chambers, Ricky Versteeg of Freshfields Bruckhaus Deringer and
Andrew Leitch of Bryan Cave Leighton Paisner. John, Emma, Ricky and Andrew gave interesting and thoughtprovoking presentations on various aspects of private damages actions, including tactics, jurisdiction and collective proceedings.

The panel on Vertical restraints in the online age: where next? was chaired by Paul Bridgeland, of DG Competition, European Commission, who provided, in his introductory remarks, an overview of the Commission's public consultation on possible changes to the Vertical Restraints Block Exemption. Presentations were given by Henry Llewellyn of Slaughter and May, Imogen Ditchfield of Freshfields Bruckhaus Deringer and Patrick Todd of Herbert Smith Freehills. They tackled a range of topical issues, including how to apply the law of vertical restraints to fast moving online and digital markets.

As is customary, each participant is invited to contribute an article to the Journal, based on their presentation to the JCC. As well as articles from John Kwan, Ricky Versteeg, Andrew Leitch and Patrick Todd, we are pleased to also publish in this issue an article, on the application of competition law to blockchain, by Lucy Chambers of Slaughter and May, who had to withdraw from the conference due to having exams the same day at King's College London. We will be publishing articles from the remaining speakers, Emma Mockford, Imogen Ditchfield and Henry Llewellyn, in a later issue.

We hope that readers will find these articles to be of interest and are sure that you will agree with us that they are excellent examples of the high quality of junior practitioners who are well placed to help shape the future development of competition law.

We are very grateful not only to our speakers and panel chairs, and Sir Peter Roth, for their excellent contributions at the JCC, but also to Julie Hamilton and her colleagues at the CAT, and Katie Smith, of Edward Elgar for their invaluable logistical and administrative support. We are also grateful to our sponsors, Edward Elgar Publishing, Euclid Law Limited, Herbert Smith Freehills LLP and St John's Chambers for their support.

We look forward to the next edition of the JCC in 2020. Please look out for announcements!

Sarah Long Andrew North Matthew O'Regan 